UNDERGRADUATE RESEARCH IN NATURAL AND CLINICAL SCIENCE AND TECHNOLOGY (URNCST) JOURNAL Read more URNCST Journal articles and submit your own today at: https://www.urncst.com

\title{
Overexpression of PDX1 and NKX6.1 as a Treatment for Type 1 Diabetes: A Research Protocol
}

\author{
Nabeeha Aftab, BSc Student [1]*, Hunaiza Arshad, BScN Student [2] \\ [1] Faculty of Science, York University, Toronto ON, M3J 1P3 \\ [2] Faculty of Nursing, Trent University, Oshawa ON, L1J 5Y1 \\ *Corresponding Author: nabeehaaftab@gmail.com
}

\begin{abstract}
Introduction: Type 1 diabetes is an autoimmune disorder characterized by the destruction of pancreatic islet beta cells responsible for insulin production, leading to insulin deficiency. The PDX1 and NKX6-1 genes are essential to beta cell development and maturation in the pancreas. Based on previous studies, Pdx1 is downregulated in diabetics, and higher Nkx6.1 expression has been shown to induce high cell turnover. This proposal aims to investigate the potential therapeutic effects of gene therapy on streptozotocin-induced non-obese diabetic/severe-combined immunodeficient mice in treating Type 1 Diabetes. It is hypothesized that the use of gene therapy to overexpress PDX1 and NKX6-1 into the pancreas of experimental diabetic mice will result in increased beta cell production and improved glucose metabolism.

Methods: Both male and female streptozotocin-induced non-obese diabetic/severe-combined immunodeficient experimental mice will receive human islets from individuals 32-55 years old. The PDX1 and NKX6-1 genes will be overexpressed in a shuttle vector and incorporated into the gutless adenovirus vector backbone through co-transfection using the Cre293/lox $\mathrm{P}$ cell line. Verification of successful vectors containing the gutless adenovirus coupled with a helper plasmid will be done using gel electrophoresis. Incubation with beta cells will stimulate the transduction process after which beta cells will be delivered into mice pancreas' through endoscopic retrograde cholangiopancreatography. An intraperitoneal glucose tolerance test, pancreatic biopsy with immunohistochemical staining, and islet calculations will be done.

Results: An intraperitoneal glucose tolerance test is expected to show improved blood glucose levels in experimental mice post-treatment, while a pancreatic biopsy with immunohistochemical staining and subsequent islet diameter and volume calculations are expected to depict an increase in the number of beta cells.

Discussion: The experimental mice are anticipated to show an improvement in blood glucose levels and increased production of beta cells following treatment due to the overexpression of PDXI and NKX6-1. The normal control mice and diabetic untreated mice are expected to show normal and high glucose levels, as well as normal and deficient beta cells respectively.

Conclusion: This proposal may provide a better understanding of the pathophysiology in Type 1 Diabetes and pave a new path for its treatment.
\end{abstract}

Keywords: regenerative medicine; gene therapy; type 1 diabetes; PDX1; NKX6-1; gutless adenovirus vector; helper plasmid; islet beta cells

\section{Introduction}

Type 1 Diabetes (T1D) is a chronic autoimmune disease characterized by the destruction of pancreatic insulin-producing beta cells ( $\beta$-cells). As a result of insulin deficiency, a hormone essential for the utilization and storage of glucose, individuals diagnosed with this condition must rely on exogenous insulin administration to regulate their body's blood glucose levels [1]. As effective as this treatment is, many diabetics continue to experience both hypo (low levels) and hyperglycemia (high levels) due to the difficulty of maintaining normal glucose levels with insulin injections [1]. Symptoms of critical deficiency of insulin resulting in hyperglycemia include polyuria (increased urination), polydipsia (increased thirst), weakness and fatigue [1]. In cases of very poor management commonly characterized by consistently high blood sugar levels over a period of years, individuals become prone to the long-term complications of diabetes which include heart disease, stroke, kidney failure, and blindness [1]. As a result, ongoing research is focused on different methods of treatment that involve the reestablishment of $\beta$-cell function and prevention of $\beta$-cell destruction. In 2018, a study done by Xiao et al. found that the use of an adeno-associated virus (AAV) to deliver and express $M A F A$ and $P D X 1$ genes encoding MAF BZIP Transcription Factor A (MafA) and Pancreas/Duodenum Homeobox Protein $1(\mathrm{Pdx} 1)$ respectively into mice results in the conversion of alpha cells ( $\alpha$-cells) to $\beta$-cells in vivo [2]. Although both genes code for transcription factors, MafA binds to promoter/ enhancer regions of the insulin 
UNDERGRADUATE RESEARCH IN NATURAL AND CLINICAL SCIENCE AND TECHNOLOGY (URNCST) JOURNAL Read more URNCST Journal articles and submit your own today at: https://www.urncst.com

gene and drives expression, while $\mathrm{Pdx} 1$ regulates the expression of more than one $\beta$-cell-specific genes including insulin and glucokinase, thereby making it essential for the development, differentiation, and maintenance of mature $\beta$ cell function [2]. Xiao et al paired Pdx1 with MafA due to the successful results of previous studies that have shown the importance of both transcription factors along with a third factor, Ngn3 (neurogenin 3) in driving the in-vivo differentiation of pancreatic exocrine cells into $\beta$-cells [3]. A similar study conducted by Banga et al. also demonstrated that simultaneous overexpression of the three genes resulted in Sox $9^{+}$cells reprogramming into $\beta$-cells [4]. As a result of such findings, the gene therapy treatment proposed by Xiao et al. used the combination of Pdx1 and MafA to induce differentiation of acinar cells into insulin producing cells [2]. The results of the study including restoration of normal blood glucose levels in non-obese diabetic/ severe combined immunodeficient (NOD/SCID) mice suggested that this treatment may be promising in treating T1D [2]. That said, research focusing on additional essential genes involved in $\beta$-cell production and new developments of viral vectors suggest a gene therapy approach encompassing a novel combination of genes that may provide more information about the disorder and a potential treatment for T1D.

Homeobox protein Nkx6.1 is a transcription factor encoded by the gene $N K X 6-1$ that is uniquely expressed in mature pancreatic $\beta$ - cells and plays a major role in the early and late development of $\beta$ - cells [5]. Pancreas transcription factor 1 subunit alpha (Ptfla) is a key transcription factor involved in directing multipotent pancreatic progenitor cells towards the acinar lineage, and studies show that Nkx6.1 and Ptfla are essential in specifying progenitor cells towards endocrine and acinar lineages respectively through the repression of the alternative lineage [6]. In addition to suppression, Nkx6.1 co-expressed with $\mathrm{Pdx} 1$ at this early stage induces cell commitment to the $\beta$-cell lineage [7]. During late development, $\mathrm{Nkx} 6.1$ functions in maintaining $\beta$-cell identity and is crucial in maintaining $\beta$-cell function including insulin production and glucose metabolism [7]. Genome wide analyses paired with functional assays have demonstrated that $\beta$-cells lacking gene expression of Nkx6.1 lose functional characteristics and exhibit loss of cell identity by acquiring characteristics of delta cells $(\delta)$, thereby confirming that Nkx6.1 expression is important for $\beta$-cell proliferation and function [8]. A similar study focusing on the effects of point mutations in the transactivation domain of the PDX1 gene on $\beta$-cell development and insulin secretion emphasized the importance of $P D X 1$ in ensuring correct endocrine lineage formation and maintenance of $\beta$-cell function [9]. Nkx6.1 interacts with many other transcription factors, and coimmunoprecipitation (Co-IP) data focusing on Nkx6.1 and $\mathrm{Pdx} 1$ provided evidence of significant binding interactions between both transcription factors [10]. In a study done by
Tran et al., it was found that Nkx6.1 overexpression is correlated with a higher turnover rate of $\beta$-cells [11].

As a result of the numerous findings regarding essential interactions among Pdx1 and Nkx6.1 and their roles in $\beta$-cell development and function, we expect that the overexpression of the NKX6-1 gene, along with $P D X 1$, would promote the development, differentiation, and maintenance of functional mature $\beta$-cells. This study aims to outline a viral gene therapy method that may be used as a potential treatment for T1D.

\section{Methods \\ Mice Selection}

All male and female non-diabetic control mice, streptozotocin (STZ)-induced NOD/SCID untreated control and treated experimental mice will be obtained from an animal research lab such as Jackson lab (Bar Harbor, Me, USA). Twenty-eight mice aged 45 weeks old belonging to the BALB/C strain will be used in all randomized and blind assessments [12]. Seven mice will be randomly assigned to each group and will be kept in an animal care facility such as Vanderbilt animal care facility while being fed a balanced standard chow and taken care of according to the institution's guidelines [13]. To ensure selection of severely NOD mice, a 6-hour fasting period followed by a blood glucose level assessment will be done and mice displaying fasting glucose levels greater than $300 \mathrm{mg} / \mathrm{dl}$ will be used [13]

\section{Collection and Use of Human Islet Cells}

Human islet cells will be obtained from non-diabetic organ donors from a facility such as the University of Chicago Transplant Centre. Independent human islet batches will be harvested for the genes of interest, PDXI and NKX6-1 which will then be isolated, overexpressed in the gutless adenovirus vector coupled to the helper plasmid (pGLAD) and introduced into mice. The human islets will be retrieved from both males and females aged 32-55 years old [2].

Vector Production

The gutless adenovirus vector will be used as a gene delivery apparatus due to its large packaging capacity, versatility, and low toxicity [14]. The adenovirus will be obtained from a manufacturer that provides proteomic and genomic products such as Thermofisher laboratories (Waltham, MA, USA). The virus vector will then be coupled with a helper plasmid to eliminate any contamination in the vector that could potentially cause acute and chronic toxicity in host cells [15].

The process starts with the amplification of the gutless adenovirus vector (GLAD) which will be done by infecting the cell monolayer from the viral stock. The cells will then be harvested and lysed to release the virus once the cytopathic effect begins to initiate. Viral purification will then be followed via centrifugation through cesium chloride 
UNDERGRADUATE RESEARCH IN NATURAL AND CLINICAL SCIENCE AND TECHNOLOGY (URNCST) JOURNAL
Read more URNCST Journal articles and submit your own today at: $\underline{\text { https://www.urncst.com }}$

gradients. When the final products are obtained, they will be desalted, then tittered using spectrophotometry to examine the viral particles [16]. A helper plasmid will be made following the methodology outlined in the paper done by Lee et al [15]. The genes of interest PDX1 and NKX6-1 will be overexpressed by sub-cloning them into the shuttle vector, part of the helper plasmid. Then, the shuttle vector will be incorporated into the GLAD backbone through cotransfection using the Cre293/lox P cell line which contains an enzyme referred to as cre recombinase [14]. This enzyme functions to improve the recombination ability of the vector and helper plasmid thereby reducing the amount of helper adenovirus contaminate to approximately $0.1 \%$ [14]. To verify and isolate the vector containing the helper plasmid and both genes, the vector will be linearized and subjected to agarose gel electrophoresis which separates fragments based on molecular size [17]. The gel will contain a kilobase pair $(\mathrm{Kb})$ ladder encompassing the known sizes of the individual components including the vector, helper plasmid, $P D X 1$ and $N K X 6-1$ genes [18]. The size of the vector containing all required components will match up to the sum of the individual components, and this is identified as pGLAD.

\section{Viral Transduction into $\beta$-cells}

PGLAD will be amplified using polymerase chain reaction (PCR). $\beta$-cells will be extracted from STZ-induced NOD/SCID experimental mice via a pancreatic biopsy. These cells will then be isolated using glucagon-like peptide-1 receptor (Glp-1r) which binds to fluorescent exendin-2 (E4) through liquid affinity chromatography [19]. Isolated $\beta$-cells will then be placed onto a petri dish with the pGLAD vector and be incubated for 10-15 days to allow for transduction to occur [15].

\section{Transfer of Genes into Mice}

The $\beta$-cells containing pGLAD will be incorporated into the pancreatic duct of the STZ-induced NOD/SCID experimental mice using a non-surgical technique called endoscopic retrograde cholangiopancreatography (ERCP). ERCP is a simple procedure that uses a long flexible tube that can inject into the bile duct. It uses a contrast dye to get an $\mathrm{X}$-ray image of the digestive tract to guide the needle [2].

\section{Intraperitoneal Glucose Tolerance Test}

An intraperitoneal glucose tolerance test (ipGTT) is used to measure the body's response to glucose [13]. After 6 hours of fasting, the first blood sample will be drawn from a tail bleed after which an intraperitoneal injection of sterile glucose $(2 \mathrm{~g} / \mathrm{kg}$ body weight) will be administered under isoflurane anesthesia [13]. Blood glucose levels will be assessed 15-, 30-, 60-, and 120-minutes following administration. The blood draw before glucose delivery will determine the baseline blood glucose levels and the subsequent draws will depict the glucose levels in response to the stimulus. These levels will be determined using a glucometer (measured in $\mathrm{mg} / \mathrm{dl}$ ). Glucose levels start to level off an hour after glucose administration, therefore levels ranging between $100-200 \mathrm{mg} / \mathrm{dl}$ approximately 60 minutes following intraperitoneal injection are normal, while values approaching and greater than $300 \mathrm{mg} / \mathrm{dl}$ indicate hyperglycemia [20]. An ipGTT will be done for both control groups before, and for experimental groups before, 1 month and 6 months after gene therapy treatment.

Pancreatic Biopsy and Immunohistochemical Staining

A pancreatic biopsy will be done to examine whether functional $\beta$-cells are being produced. A section of pancreatic tissue from STZ-induced NOD/SCID experimental mice will be extracted laparoscopically using biopsy forceps, ensuring to avoid any major vessels and cauterize any bleeds in the process [21]. The tissue sample will be examined in closer detail in a lab. The tissue containing the cells will be placed in staining plates and will be fixed in zinc for 6 hours followed by $4 \%$ formalin before immunohistochemical staining [2]. Anti- insulin antibody immunoperoxidase with diaminobenzidine reaction $(\mathrm{DAB})$ and hematoxylin counterstaining will be done to stain the $\beta$-cells and islets within which they are contained respectively [22]. Visual staining will be accompanied by numerical measurements of the islet diameter and calculations for islet volume size using the formula $4 / 3 \pi r^{3}$ ( $r=$ radius) [12]. A pancreatic biopsy will be done for all three groups before, and for NOD experimental mice 6 months following treatment. 
UNDERGRADUATE RESEARCH IN NATURAL AND CLINICAL SCIENCE AND TECHNOLOGY (URNCST) JOURNAL

Read more URNCST Journal articles and submit your own today at: https://www.urncst.com

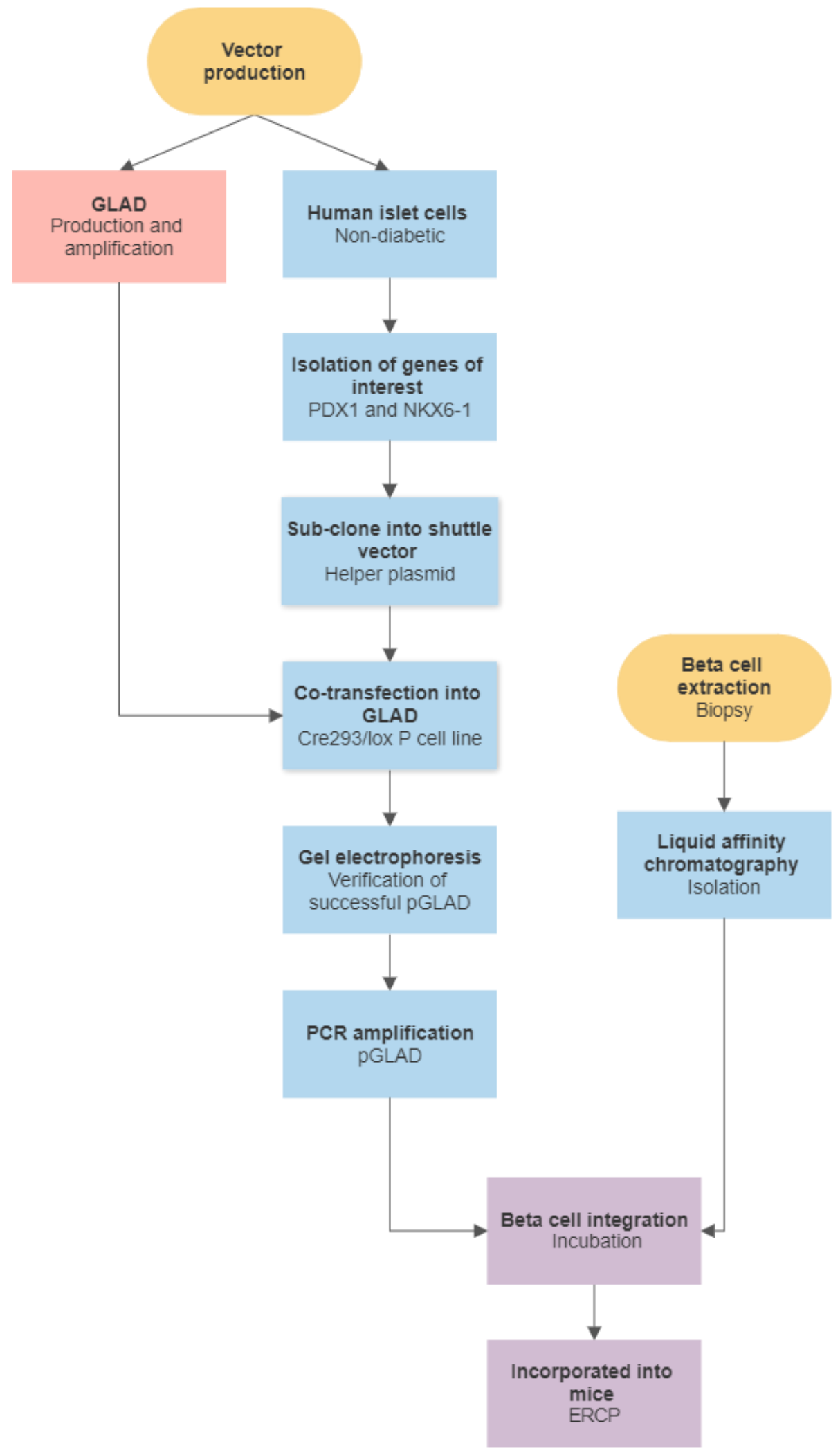

Figure 1. Depiction of experimental design, created using Smartdraw. 
UNDERGRADUATE RESEARCH IN NATURAL AND CLINICAL SCIENCE AND TECHNOLOGY (URNCST) JOURNAL Read more URNCST Journal articles and submit your own today at: https://www.urncst.com

\section{Results}

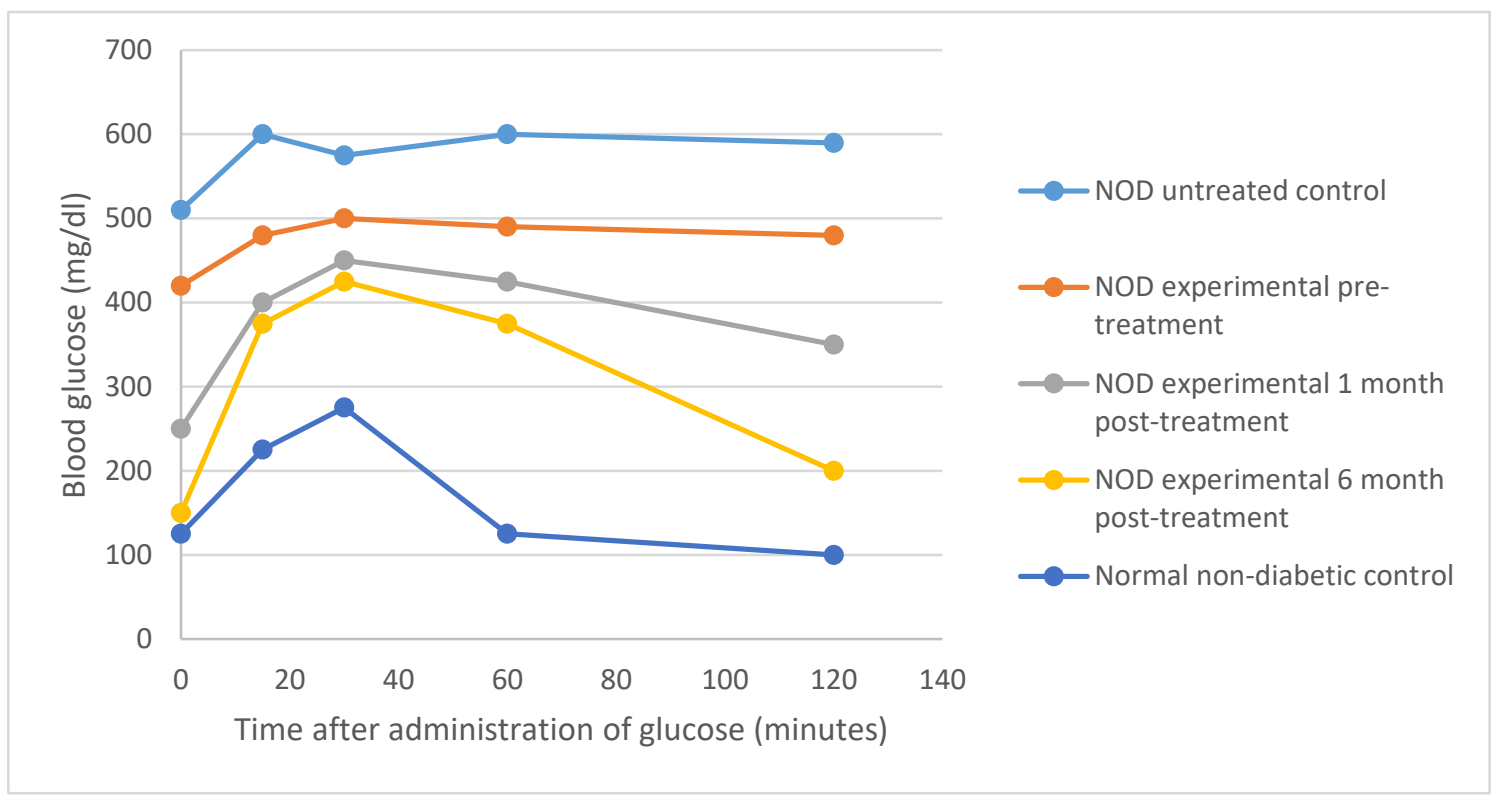

Figure 2. Line graph depicting the results of an intraperitoneal glucose tolerance test illustrating the blood glucose levels of BALB/C non-diabetic control mice, NOD untreated control mice and NOD experimental mice before, 1 month after, and 6 months after treatment over a period of 120 minutes each time [13]. This graph was created using Microsoft Excel.

A.

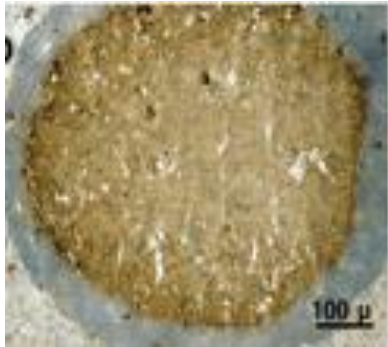

B.

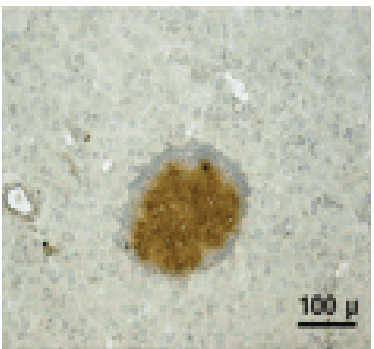

C.

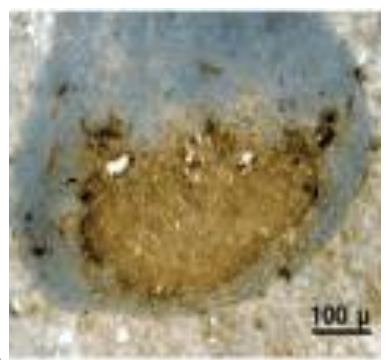

Figure 3. Immunohistochemistry of islet $\beta$-cells from pancreatic tissue. Anti- insulin antibody immunoperoxidase with diaminobenzidine reaction (DAB) and hematoxylin counterstaining is used to stain the $\beta$-cells (brown) and islets (blue), respectively. One mouse from each sample group is randomly selected. A depicts the size of $\beta$ - cell islets in non-diabetic control mice. B represents the results of NOD control mice and NOD experimental mice prior to treatment. C illustrates the results of the NOD experimental mice 6 months following gene therapy treatment [12]. Images adapted from Chong et al., reprinted with permission from American Association for the Advancement of Science [12]. 
UNDERGRADUATE RESEARCH IN NATURAL AND CLINICAL SCIENCE AND TECHNOLOGY (URNCST) JOURNAL

Read more URNCST Journal articles and submit your own today at: https://www.urncst.com

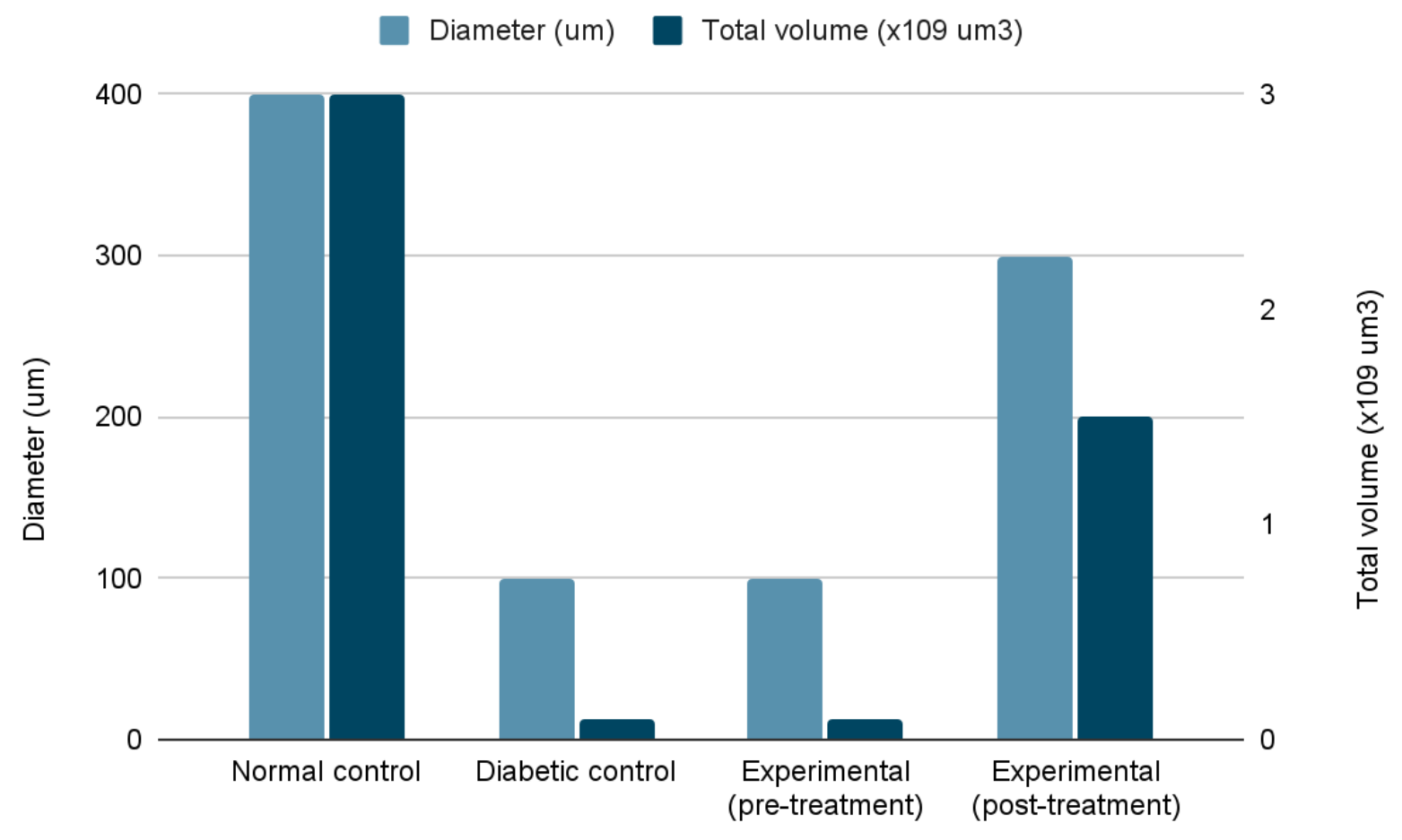

Figure 4. Bar graph produced on Microsoft Excel depicting the average measured diameter and calculated volume of $\beta$-cell islets in all three groups before treatment and 6 months following treatment for NOD experimental mice.

We expect the results of this study to illustrate that the non-diabetic control mice will have regular blood glucose levels ranging between 100-150 mg/dl and NOD untreated control mice will depict glucose levels greater than 300 $\mathrm{mg} / \mathrm{dl}$ indicative of hyperglycemia (high blood sugar) 60 minutes after glucose intake, as illustrated in Figure 2 [20]. Moreover, the NOD experimental mice are expected to show improvements in blood glucose levels following treatment. As illustrated in Figures 3 and $\underline{4}$, the non-diabetic control and NOD untreated mice are expected to show a greater and smaller islet diameter and volume respectively. We anticipate the NOD experimental mice to depict an increase in the islet cell diameter and volume following treatment. The expected results provide support for this gene therapy treatment being successful in treating T1D.

\section{Discussion}

Major components of the proposed experimental design as outlined in Figure 1 are constructed based on successful methodologies used in multiple studies. The study conducted by Lee et al highlighted a method for vector production that consisted of novel construction of a helper plasmid which was then coupled to GLAD in order to produce a pGLAD vector [15]. The pGLAD was used to introduce the dystrophin gene into mice models and proved to be successful as the vector-maintained gene expression in the target tissue for at least 4 weeks [15]. In addition, this vector has been shown to provide benefits that a typical adenovirus vector (AVV) would not, including long-term transgene expression, reduced contamination, and a much lower immune response which is important when aiming to treat an autoimmune disorder [15]. Moreover, the genes PDX1 and NKX6-1 will be used in combination due to the importance of each encoded transcription factor in $\beta$-cell production, differentiation, and survival [7,8,9]. To eliminate chances of toxicity within the host, the Cre293/lox P cell line will be used as it contains cre recombinase which ultimately functions to reduce the chances of viral genome integration into the co-transfected pGLAD [14]. In addition, when introducing the cells into mice, the technique referred to as ERCP is favoured due to its non-invasive nature allowing for a safe and efficient delivery into the target tissues [2].

The expected results of the intraperitoneal glucose tolerance test, immunohistochemistry and calculations of islet cell diameter and volume before and after our proposed gene therapy treatment should confirm the hypothesis that the overexpression of PDX1 and NKX6-1 result in an increased production of functional pancreatic islet $\beta$-cells. The results applicable to the non-diabetic control mice and NOD untreated control mice should remain consistent throughout the experiment, while the NOD experimental mice are expected to show improvements in all tests conducted. 
UNDERGRADUATE RESEARCH IN NATURAL AND CLINICAL SCIENCE AND TECHNOLOGY (URNCST) JOURNAL Read more URNCST Journal articles and submit your own today at: https://www.urncst.com

Several studies have used ipGTT for different purposes, for example Gunawardana and Piston conducted a study in which ipGTT was used as a test to assess if subcutaneous transplants of brown adipose tissue introduced into STZ-induced diabetic mice that lost adipose tissue corrected T1D [13], while a separate study focusing on Type 2 diabetes used ipGTT to determine the effect of obesity on glucose metabolism [23]. Due to the common use of this test as part of testing protocol in diabetes related studies, we decided to use it as one of our measures for glucose metabolism. This test would be done on all 3 groups of mice before and on NOD experimental mice 1month and 6-month post treatment. Blood glucose levels between $100-150 \mathrm{mg} / \mathrm{dl}$ at any given time are deemed normal, while values approaching, and exceeding $300 \mathrm{mg} / \mathrm{dl}$ are representative of diabetic hyperglycemia [20]. Before gene therapy treatment, the results of the ipGTT shown in Figure 2 illustrate that after 6 hours of fasting, the baseline levels of non-diabetic control mice are approximately 100$150 \mathrm{mg} / \mathrm{dl}$, while NOD untreated control and NOD experimental mice are between $400-500 \mathrm{mg} / \mathrm{dl}$. Following the intraperitoneal injection, glucose levels are measured over a 120-minute time frame. In the figure, the initial spike in blood glucose levels 15-30 minutes after the injection across all 3 groups is representative of a postprandial spike defined as plasma glucose levels greater than $140 \mathrm{mg} / \mathrm{dl}$ approximately 1-2 hours after administration of food, in this case glucose [24]. The levels are expected to drop around the 1-hour mark and stabilize. After 2 hours, all three groups of mice stabilize in the same baseline range they begun. This result illustrates the fact that the normal control mice are non-diabetic and therefore have sufficient $\beta$-cells regulating glucose metabolism, thereby allowing for insulin to be released following a glucose injection and maintaining plasma glucose levels within a normal range [20]. Similarly, the NOD mice that lack sufficient functional $\beta$-cells because of the bodily immune response show glucose values indicative of hyperglycemia in response to glucose due to impairments in insulin secretion. One month after gene therapy treatment in NOD experimental mice, the baseline and stabilizing plasma glucose levels are expected to be lower, and a 6-month follow up is expected to show further improvements thereby providing evidence of improved insulin secretion.

Moreover, $\beta$ - cells are the predominant cell type in healthy pancreatic islets making up 50-80\% of all islet cells [25], therefore in addition to ipGTT, immunohistochemical staining and subsequent measurement of islet diameter and volume is expected to provide information about novel $\beta$ cell production. This means of analysis was used in a study focusing on curing T1D through simultaneous reversal of autoreactivity and re-establishment of $\beta$ - cell function in NOD mice [12].The results depicted in Figures 3 and $\underline{4}$ are based on work done by Chong et al [12]. Figure 3 depicts the stained sections of 3 randomly selected mice, one from each group. Non-diabetic control mice are expected to show a relatively greater number of $\beta$ - cells within an islet which would also result in a greater average islet diameter and volume relative to the other 2 groups. As shown in Figure 4 , the volume calculated using the formula $4 / 3 \pi \mathrm{r}^{3}$ ( $\mathrm{r}=$ radius of islets) and diameter of normal control mice are expected to reach approximately $3 \times 10^{9} \mu^{3}$ and $400 \mu \mathrm{m}$ respectively. The NOD untreated mice and NOD experimental mice before treatment are expected to exhibit a significantly smaller islet size with fewer $\beta$ - cells as shown in Figure 3. The visual is accompanied by numerical values in Figure 4 as the expected volume is less than 1 $\mathrm{x} 10^{9} \mu \mathrm{m}^{3}$ and the islet diameter is shown to be 4 times smaller than the non-diabetic mice. The NOD experimental mice post treatment are expected to show improvements in $\beta$ - cell production and therefore an increase in the diameter and volume of islets as depicted in Figures 3 and $\underline{4}$. As done in the study, the slides will be closely examined through microscopy to ensure that the increase in pancreatic islet size of NOD experimental mice is not a result of hypertrophy, but an increase in the number of $\beta$ - cells produced [12].

Although evidence stated throughout this paper suggests the potential success of this gene therapy treatment, the proposal is not without drawbacks. The autoimmune destruction of $\beta$ - cells by autoreactive T-cells in T1D poses a risk of attack of the newly produced $\beta$ - cells resulting in the loss of insulin production [26,27]. That said, it may be possible in the future to supplement the design with immunosuppression to address this problem. A study done by Wong et al demonstrated that the administration of a subcutaneous injection of an immunosuppressive peptide, the core peptide (CP) in non-obese mice induced with diabetes using cyclophosphamide resulted in successful suppression of T-cell activation [26]. The results of a similar study done by Mahkne et al illustrated that dendritic cells induced to produce $\mathrm{CP}$ in mice were able to sufficiently suppress T-cell activation in a localized antigen specific manner that did not affect other cells, thereby providing evidence for the use of $\mathrm{CP}$ in controlling in vivo immune responses [27]. The use of CP with gene therapy may not only allow for novel production of $\beta$ - cells but also provide protection of the islets from T-cell mediated destruction. Furthermore, research focused on T1D has used mice animal models to test hypotheses and draw conclusions that may be useful in understanding disease generation and progression in humans [28,29]. However, researchers have identified differences in the anatomical divisions and structure of islets in mice versus humans, which may strain the extent to which this research can be applied to humans [30]. Pancreatic islets consist of four types of secretory cells; $\beta$ cells, $\alpha$ cells, $\delta$ cells, and pp cells producing insulin, glucagon, somatostatin, and pancreatic polypeptide respectively [7].It was discovered that $\beta$ - cells made up $80 \%$ of the constituents of mice islets but humans contained a lower percentage of $\beta$ - cells compared to $\alpha$ and $\delta$ cells, making up $50-60 \%$ of the islet volume $[7,31]$. In 
UNDERGRADUATE RESEARCH IN NATURAL AND CLINICAL SCIENCE AND TECHNOLOGY (URNCST) JOURNAL Read more URNCST Journal articles and submit your own today at: https://www.urncst.com

addition, mice islets contain a $\beta$ - cell core with $\alpha, \delta$, and pp cells in the periphery while human islets contain a mixture of all cell types throughout the islet [7,31]. Due to the $\beta$ - cells in human islets making direct contact with others in the islet, this distributional difference may suggest differences in cell communication that can affect the function of insulin producing cells [7,31]. This suggests that human islets should be studied directly, but animal models are still essential in providing relevant information and should be used. Lastly, at this stage, this research proposal is directly focused and solely applicable to the treatment of T1D because although type 1 and type 2 diabetes share characteristics such as significant hyperglycemia, they differ vastly in the pathophysiology and underlying mechanisms contributing to each disorder [26]. That said, potentially successful mice and human trials in the future may allow for this design to be applicable to more than just T1D.

\section{Conclusion}

This research protocol outlines a detailed viral gene therapy in which the genes $P D X 1$ and $N K X 6-1$ are delivered and overexpressed in the pancreas with the help of a gutless adenovirus vector coupled to a helper plasmid. In the past, a similar experimental design has shown promising results in treating T1D with gene therapy [2]. Although the combination of genes proposed in this design differs from those used in the past [2], evidence surrounding the importance of $P D X 1$ and NKX6-1 genes in $\beta$ - cell survival, differentiation and function makes this proposal a novel and potentially important gene therapy treatment in reestablishing $\beta$ - cell mediated insulin secretion. If the results are as expected, this approach may provide a better understanding of the pathophysiology of T1D and pave a new treatment for T1D that can save millions of lives. Future directions for this research should focus on mice trials which may include the incorporation of additional variables such as stress to test whether a stress-induced immune response has an impact on the survival and function of islet $\beta$ - cells.

\section{List of Abbreviations}

T1D: type 1 diabetes

$\beta$-cells: beta cells

$\alpha$ cells: alpha cells

$\delta$ cells: delta cells

MafA: MAF BZIP transcription factor A

Pdx1: pancreas/duodenum homeobox protein 1

Nkx6.1: NKX Homeobox protein 1

Ptf1a: pancreas transcription factor 1 subunit alpha

AAV: adeno-associated virus

GLAD: gutless adenovirus vector

PCR: polymerase chain reaction

PGLAD: gutless adenovirus vector coupled to helper plasmid Glp-1r: glucagon-like peptide-1 receptor

NOD/SCID: non-obese diabetic/ severe combined

immunodeficient

Aftab et al. | URNCST Journal (2021): Volume 5, Issue 10

DOI Link: https://doi.org/10.26685/urncst.286
E4: fluorescent exendin-2

$\mathrm{Kb}$ : kilobases

DNA: deoxyribonucleic acid

ipGTT: intraperitoneal glucose tolerance test

ERCP: endoscopic retrograde cholangiopancreatography

$\mu \mathrm{m}^{3}$ : cubic micrometer

$\mu \mathrm{m}$ : micrometer

$\mathrm{CP}$ : core protein

Co-IP: co-immunoprecipitation

\section{Conflict of Interest}

All authors declare that they have no conflict of interest.

\section{Ethics Approval and/or Participant Consent}

Due to the prospective nature of our research, ethics approval and/or participant consent has not been conducted but may be required in the future.

\section{Author Contributions}

NA: Provided significant contribution to the research protocol design, drafted the manuscript and gave final approval of the version to be published.

HA: Provided significant contribution to the research protocol design, drafted the manuscript and gave final approval of the version to be published.

\section{Acknowledgments}

Many thanks to Mohammad Chahrour, who was our mentor and editor for this paper and to both Althea Kho and Mohammad Yousaf Moosa for contributing to the initial research design and content.

\section{Funding}

This study was not funded.

\section{References}

[1] Kahanovitz, L., Sluss, P. M., \& Russell, S. J. Type 1 diabetes - A clinical perspective. Point of Care. 2017;16(1):37-40. https://doi.org/10.1097/POC.0000 000000000125

[2] Xiao, X., Guo, P., Shiota, C., Zhang, T., Coudriet, G.M., Fischbach, S., Prasadan, K., Fusco, J., Ramachandran, S., Witkowski, P., Piganelli, J.D. and Gittes, G.K. Endogenous reprogramming of alpha cells into beta cells, induced by viral gene therapy, reverses autoimmune diabetes. Cell Stem Cells. 2018; 22(1):7890. https://doi.org/10.1016/j.stem.2017.11.020

[3] Ersin Akinci, Anannya Banga, Lucas V. Greder, James R. Dutton, Jonathan M. W. Slack.

Reprogramming of pancreatic exocrine cells towards a beta $(\beta)$ cell character using Pdx1, Ngn3 and MafA. Biochemical Journal. 2012;442(3):539-550. https://doi.org/10.1042/BJ20111678 
UNDERGRADUATE RESEARCH IN NATURAL AND CLINICAL SCIENCE AND TECHNOLOGY (URNCST) JOURNAL Read more URNCST Journal articles and submit your own today at: https://www.urncst.com

[4] Anannya Banga, Ersin Akinci, Lucas V. Greder, James R. Dutton, Jonathan M. W. Slack. In vivo reprogramming of Sox $9+$ cells in the liver to insulinsecreting ducts. Proceedings of the National Academy of Sciences. 2012;109(38):15336-15341. https://doi.org/ 10.1073/pnas.1201701109

[5] Gefen-Halevi, S., Rachmut, I. H., Molakandov, K., Berneman, D., Mor, E., Meivar-Levy, I., \& Ferber, S. NKX6.1 promotes PDX-1-induced liver to pancreatic $\beta$-cells reprogramming. Cellular Reprogramming. 2010;12(6):655-664. https://doi.org/10.1089/cell.2010 .0030

[6] Schaffer, A. E., Freude, K. K., Nelson, S. B., \& Sander, M. Nkx6 transcription factors and Ptf1a function as antagonistic lineage determinants in multipotent pancreatic progenitors. Developmental Cell. 2010;18(6):1022-1029. https://doi.org/10.1016/ j.devcel.2010.05.015

[7] Aigha, I.I., Abdelalim, E.M. NKX6.1 transcription factor: A crucial regulator of pancreatic $\beta$ cell development, identity, and proliferation. Stem Cell Research and Therapy. 2020;11:459. https://doi.org/ 10.1186/s13287-020-01977-0

[8] Taylor, B. L., Liu, F. F., \& Sander, M. Nkx6.1 is essential for maintaining the functional state of pancreatic beta cells. Cell Reports. 2013;4(6):12621275. https://doi.org/10.1016/j.celrep.2013.08.010

[9] Wang, X., Sterr, M., Ansarullah, Burtscher, I., Böttcher, A., Beckenbauer, J., Siehler, J., Meitinger, T., Häring, H. U., Staiger, H., Cernilogar, F. M., Schotta, G., Irmler, M., Beckers, J., Wright, C., Bakhti, M., \& Lickert, H. Point mutations in the PDX1 transactivation domain impair human $\beta$-cell development and function. Molecular Metabolism. 2019;24:80-97. https://doi.org/10.1016/j.molmet.2019 .03 .006

[10] Connor C. Littlefield, Nathanael C. Jensen, Jonathon T. Hill, John C. Price, Jeffery S. Tessem. Defining the Nkx6.1 interactome in beta cells reveals a novel interaction with Pdx. diabetes. 2021;70(1):1242. https://doi.org/10.2337/db21-1242-P

[11] Tran, R., Moraes, C. and Hoesli, C.A. Controlled clustering enhances PDX1 and NKX6.1 expression in pancreatic endoderm cells derived from pluripotent stem cells. Scientific Reports. 2020;10(1):1-12. https://doi.org/10.1038/s41598-020-57787-0

[12] Chong, A. S., Shen, J., Tao, J., Yin, D., Kuznetsov, A., Hara, M., \& Philipson, L. H. Reversal of diabetes in non-obese diabetic mice without spleen cell-derived $B$ cell regeneration. Science. 2006;311(5768):1774-1775. https://doi.org/10.1126/science.1123510

[13] Gunawardana, S. C., \& Piston, D. W. Reversal of type 1 diabetes in mice by brown adipose tissue transplant. Diabetes. 2012;61(3):674-682. https://doi.org/10.2337/ $\underline{\mathrm{db} 11-0510}$

Aftab et al. | URNCST Journal (2021): Volume 5, Issue 10

DOI Link: https://doi.org/10.26685/urnest.286
[14] Alba, R., Bosch, A., \& Chillon, M. Gutless adenovirus: Last-generation adenovirus for gene therapy. Gene therapy. 2005;12(1):18-27. https://doi.org/10.1038/ sj.gt.3302612

[15] Lee, D., Liu, J., Junn, H.J., Lee, E.J., Jeong, K.S. and Seol, D.W. No more helper adenovirus: Production of gutless adenovirus (GLAd) free of adenovirus and replication-competent adenovirus (RCA) contaminants. Experimental \& Molecular Medicine. 2019;51(10): 118. https://doi.org/10.1038/s12276-019-0334-Z

[16] Guo P. El-Gohary Y., Prasadan K. Shiota C., Xiao X., Wiersch J., Paredes J., Tulachan S., Gittes G.K. Rapid and simplified purification of recombinant adenoassociated virus. Journal of Virological Methods. 2012;183:139-146. https://doi.org/10.1016/j.jviromet .2012 .04 .004

[17] Jacobus, A. P., \& Gross, J. Optimal cloning of PCR fragments by homologous recombination in Escherichia coli. PloS One. 2015;10(3). https://doi.org/ 10.1371/journal.pone.0119221

[18] Zhang, J. H., Yang, R., Wang, T. Y., Dong, W. H., Wang, F., \& Wang, L. A simple and practical method that prepares high molecular weight DNA ladders. Molecular Medicine Reports. 2012;6(5):1211-1213. https://doi.org/10.3892/mmr.2012.1061

[19] Clardy, S. M., Mohan, J. F., Vinegoni, C., Keliher, E. J., Iwamoto, Y., Benoist, C., Mathis, D., \& Weissleder, R. Rapid, high efficiency isolation of pancreatic Bcells. Scientific reports. 2015;5:13681. https://doi.org/ 10.1038/srep13681

[20] Han, B. G., Hao, C.-M., Tchekneva, E. E., Wang, Y.Y., Lee, C. A., Ebrahim, B., Harris, R. C., Kern, T. S., Wasserman, D. H., Breyer, M. D., \& Qi, Z. Markers of glycemic control in the mouse: Comparisons of 6-hand overnight-fasted blood glucoses to $\mathrm{Hb}$ A1c. American Journal of Physiology-Endocrinology and Metabolism. 2008;295(4). https://doi.org/ 10.1152/ajpendo.90283.2008

[21] Itoh, N., Hanafusa, T., Miyazaki, A., Miyagawa, J. I., Yamagata, K., Yamamoto, K., \& Inada, M. Mononuclear cell infiltration and its relation to the expression of major histocompatibility complex antigens and adhesion molecules in pancreas biopsy specimens from newly diagnosed insulin-dependent diabetes mellitus patients. The Journal of Clinical Investigation. 1993;92(5):2313-2322. https://doi.org/ 10.1172\%2FJCI116835

[22] Jouvion, G., Abadie, J., Bach, J. M., Roux, F., Miclard, J., Deschamps, J. Y., Guigand, L., Saï, P., \& Wyers, M. Lymphocytic insulitis in a juvenile dog with diabetes mellitus. Endocrine Pathology. 2006;17(3):283-290. https://doi.org/10.1385/ep:17:3:283 
UNDERGRADUATE RESEARCH IN NATURAL AND CLINICAL SCIENCE AND TECHNOLOGY (URNCST) JOURNAL Read more URNCST Journal articles and submit your own today at: https://www.urncst.com

[23] Dinger, K., Mohr, J., Vohlen, C., Hirani, D., Hucklenbruch-Rother, E., Ensenauer, R., Dötsch, J., \& Alejandre Alcazar, M. A. Intraperitoneal glucose tolerance test, measurement of lung function, and fixation of the lung to study the impact of obesity and impaired metabolism on pulmonary outcomes. Journal of Visualized Experiments. 2018;(133):56685. https://doi.org/10.3791/56685

[24] Hiyoshi, T., Fujiwara, M., \& Yao, Z. Postprandial hyperglycemia and postprandial hypertriglyceridemia in type 2 diabetes. Journal of Biomedical Research. 2017;33(1):1-16. https://doi.org/10.7555/JBR.31.20160164

[25] Marchetti, P., Bugliani, M., De Tata, V., Suleiman, M., \& Marselli, L. Pancreatic beta cell identity in humans and the role of type 2 diabetes. Frontiers in Cell and Developmental Biology. 2017;5:55. https://doi.org/ 10.3389/fcell.2017.00055

[26] Wong, M. S., Hawthorne, W. J., \& Manolios, N. Gene therapy in diabetes. Self/nonself. 2010;1(3):165-175. https://doi.org/10.4161/self.1.3.12643

[27] Mahnke, K., Qian, Y., Knop, J., \& Enk, A. H. Dendritic cells, engineered to secrete a T-cell receptor mimic peptide, induce antigen-specific immunosuppression in vivo. Nature Biotechnology. 2003;21(8):903-908. https://doi.org/10.1038/nbt842
[28] Van Belle, T. L., Taylor, P., \& von Herrath, M. G. Mouse models for type 1 diabetes. Drug Discovery Today - Disease Models. 2009;6(2):41-45. https://doi.org/10.1016/j.ddmod.2009.03.008

[29] Atkinson, M., Leiter, E. The NOD mouse model of type 1 diabetes: As good as it gets? Nature Medicine. 1999;5:601-604. https://doi.org/10.1038/9442

[30] Brissova, M., Fowler, M. J., Nicholson, W. E., Chu, A., Hirshberg, B., Harlan, D. M., \& Powers, A. C. Assessment of human pancreatic islet architecture and composition by laser scanning confocal microscopy. The Journal of Histochemistry and Cytochemistry: Official Journal of the Histochemistry Society. 2005;53(9):1087-1097. https://doi.org/ 10.1369/jhc.5C6684.2005

[31] Cabrera, O., Berman, D. M., Kenyon, N. S., Ricordi, C., Berggren, P. O., \& Caicedo, A. The unique cytoarchitecture of human pancreatic islets has implications for islet cell function. Proceedings of the National Academy of Sciences of the United States of America. 2006;103(7):2334-2339. https://doi.org/ 10.1073/pnas.0510790103

\section{Article Information}

Managing Editor: Jeremy Y. Ng

Peer Reviewers: Jala Rizq, Siobhan O’Brien

Article Dates: Received May 05 28; Accepted Oct 07 21; Published Oct 2721

\section{Citation}

Please cite this article as follows:

Aftab N, Arshad H. Overexpression of PDX1 and NKX6.1 as a treatment for type 1 diabetes: A research protocol. URNCST Journal. 2021 Oct 27: 5(10). https://urncst.com/index.php/urncst/article/view/286

DOI Link: https://doi.org/10.26685/urncst.286

\section{Copyright}

(C) Nabeeha Aftab, Hunaiza Arshad. (2021). Published first in the Undergraduate Research in Natural and Clinical Science and Technology (URNCST) Journal. This is an open access article distributed under the terms of the Creative Commons Attribution License (https://creativecommons.org/licenses/by/4.0/), which permits unrestricted use, distribution, and reproduction in any medium, provided the original work, first published in the Undergraduate Research in Natural and Clinical Science and Technology (URNCST) Journal, is properly cited. The complete bibliographic information, a link to the original publication on http://www.urncst.com, as well as this copyright and license information must be included. 
UNDERGRADUATE RESEARCH IN NATURAL AND CLINICAL SCIENCE AND TECHNOLOGY (URNCST) JOURNAL

Read more URNCST Journal articles and submit your own today at: https://www.urncst.com

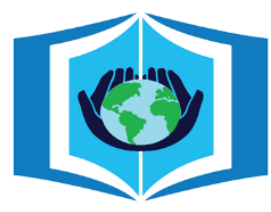

\section{URNCST Journal \\ "Research in Earnest"}

\section{Funded by the Government of Canada}

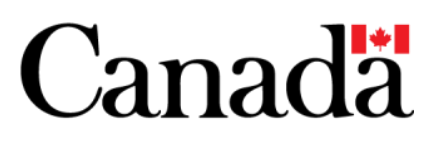

Do you research in earnest? Submit your next undergraduate research article to the URNCST Journal!

| Open Access | Peer-Reviewed | Rapid Turnaround Time | International | | Broad and Multidisciplinary | Indexed | Innovative | Social Media Promoted |

Pre-submission inquiries? Send us an email at info@ urncst.com | Facebook, Twitter and LinkedIn: @URNCST Submit YOUR manuscript today at https://www.urnest.com! 